\title{
CHALLENGES OF GIRL-CHILD EDUCATION IN A PERIOD OF RECESSIVE
} ECONOMY IN NIGERIA

\section{UMAR MAIMUNA RABO (Mrs.)}

\begin{abstract}
Education has been identified as a developmental tool of which no nation could develop with out. Sustainable development could only be achieved with the contributions of both sexes, as women play a significant role in the development of any society. The paper traces the geneses of girl child education in economic recession, so also the relevance of girl child education in economic development such as man power, shills capacity development. The challenges facing girl child education which include illiteracy, extreme poverty and socio cultural factors. The paper suggested among others, that govermment should not only make girl child education free but also compulsory at all levels to prevent drop out as a result of lack of funding.
\end{abstract}

\section{INTRODUCTION}

The development of any nation is based on the positive contribution of its citizens, and for each citizen to give meaningful contribution his/her rights most be met. Nigeria as a country has been striving to develop like any other developed countries of the world. Yet it has not been able to actualize its dream due to the fact that a certain percentage (female) of its citizens has been denied the right to education. It is a known fact that education is the backbone and foundation of any nation's development.

Kane, (1995) stated that two thirds of those who cannot read and write are women, 60 percent of children not in school are girls. The issue of girl child education has been discussed and debated by various organizations (both governmental and non-governmental) individuals too have made enormous contributions to this issue. Gurian (2001) writes "train boys and girls in their "nature" giving them training and material similar to what teachers get regarding gender brain difference and similarities. This means that training is not a masculine issue only, it is also a feminine issue. Nature demands that every human being born should be trained, no matter the differences in the way their brain are receptive to knowledge. Nature encourages the acquisition of knowledge by those in His image and likeness and that include man and woman (Kane 1995).

\section{Concept of Girl-Child Education}

The concept of girl-child/women education essentially has to do with the training and inculcation of desirable attitudes, values, skills and aptitudes that will enable them to be useful to themselves and contribute to the survival and progress of the society in general (Manga, 2003)

According to Odaga and Heneveld (as cited in Mamza 2003) women/girl child education is the giving of female child the opportunity of being knowledgeable in school and out side school. It is also the giving of female children fair equal chance like the male children in 
performing social, economic and political roles in the society.

Many organizations and agencies identified the education of women and girls as a key factor necessary for socioeconomic and political empowerment. This means that governments should recognize the potentials of women and their untapped human resources for national development (Muhammad. 2007).

In pursuance of the slogan "Educate a woman educate a Nation", the United Nations in article 10 of the 1979 convention on the Elimination of all forms of discrimination Against women (CEDAW) declared that countries should:

Provide access to the same curricula, examination and quality teaching as boys'

- Eliminate any stereotyped concept of the role of women and men by revising text book and school programme and adapting teaching methods to the needs of girls.

Offer the same opportunities for career and vocation guidance and scholarship and study grants.

Promote the active participation of girls in sport and physical education.

Make available the same opportunities in programmes for continuing education, including adult and functional literacy programmes.

Reduce female dropout rate, organize programmes for girls and women who have-left school prematurely.

\section{Concept of Economic Recession}

Wikipedia reports (2010) broadly defined, a recession as a downturn in a nation's economic activity. The consequences typically include increased unemployment, decreased consumer and business spending and declining stock prices. Recessions are typically shorter than the period of economic expansion that they follow, but they can be quite severe even if brief. Recovery is slower from some recessions than from others.

\section{Causes of Economic Recession in Nigeria}

Wikipedia reports (2010) also highlight the following as the major causes of economic recessions:

Overdependence of the nations on petroleum as a source of income: According to the CBN Governor, Nigeria gets over $95 \%$ of its revenue from oil.

Resource mismanagement (not just petroleum, but natural gas as well); Countries like Malaysia and Singapore in the 1970s had the same revenue with Nigeria but today make more than 11 times the revenue of Nigeria.

High rate of importation:- This has been a great menace to the Nigerian economy as a many commodities are imported and on the long run other economies benefit from Nigeria. For example many electronic products are imported from china.

The debt game; Nigeria as a country is still heavily indebted to the World 
Bank and International Monet xry Fund (IMF).

The changing dynamics of over population has also affected the Nigerian economy because adequate plan have not been put in place for the nation's increasing population.

Outright corporate greed exhibited by various companies and service providers also have a major contribution to the economic situation in the country.

The national relocation of employment and the changing of means of labour also have a part. Many people are migrating to major cities like Lagos, Abuja, Port Harcourt causing these cities to be over populated and few people left to farm in the other states(Wikipedia reports (2010))

\section{Education in a Period of Economic Recession}

The National Policy on Education (2004) states that "education is an interaction for national development and the interaction of persons and levels, their integration for national development and the interaction of persons and ideas are all aspects of education, education esters the worth and development of the society, there is need for functional education for the general development of the individual sake. and for the promotion of a progressive united Nigeria. Luler (1989) also pointed out the fact that education is a major tool for national development. As a nation desires to catch up with the developed world, education is regarded as an instrument per excellence for national development. This brought the issue of economic recession or milt down in Nigeria which is a stumbling block for national development. (Wikipedia reports 2010). After several years of rapid growth in developing countries such as Nigeria, the financial melt-down has ushered in dramatic shifts in the economy at all levels and more broadly, for social development and achievement of the millennium goals 2 (free and compulsory education for all boys and girls of school age). The crisis comes at a time of impressive progress in getting more children into school, with primary school environments across sub-Saharan Africa increasing at a much faster rate than in the 1990 s.

This is especially true in the case of Nigeria which has made little progress to widen access to primary education. To keep up this momentum low-income countries face the challenges of expanding access, building more classrooms, training and hiring more teachers and improving the quality of learning at all level. (Wikipedia 2010). Like much of the nation, Nigeria's public schools are in dire financial straits. In this recession, nearly every state in Nigeria has less to spend on education. Private schools bracing for sharp fall in number during the recession are also going to extraordinary length to hold on to students. There has been a surge in parents requesting fee reductions and some schools are even offering credit to struggling families. 
Already, before this worldwide recession, the Nigeria educational system has been on a downward slope. But the situation was much worse before the advent of decay in 1999 when the Universal Basic Education was commissioned to improve and widen access for primary education (Wikipedia, 2010). Before then. budgeting allocation to education fell short of the prescribed 26 percent of the entire budgeting allocation. It only improved slightly when democracy berthed in 1999. Even at that budgeting and UBEC interventions in all the thirty six states amounted to just a little drop in the ocean considering the years of neglect of public education. Matters have become worse since then. Allegations of corruption has continued to dog the States Universal Basic Education Commission which has been to patronize agencies by successive governors. The result, was that more children dropped out of schools to dilapidated infrastructures in public schools which makes them no better than detention centers.

A visit to any of Nigeria's public schools at all levels will reveal a nation whose education. Policy makers have perfected official deceit as an art. How could Nigeria possibly be among the world's twenty economies by 2020 with the state of its public education? With the state of public education at all levels, vision 2020 will be a mirage.

Which future leaders drive this vision when majority of children study on bare floors? When there is extreme gender imbalance and Nigeria recently listed as third among countries with the highest number of out-of-school children world wide? (Wikipedia Report. 2010).

\section{Girl-Child Education in A Period of Economic Recession}

Badejo (1991) opined that education is not only a basic human right. but is a key to social progress. Illiteracy and lack of education and training in basic skills contribute to the vicious cycle of underdevelopment. Therefore, an atmosphere has to be built to make it possible for girls to abandon work and enroll into school. The education of girls through attendance in full time schools is crucial to liberate them. Education enables them to cope with problem of gender discrimination. In fact, they become well-equipped to deal with adverse situations. Schooling opens up options and possibilities, new dreams and a newer future. More than anything else school provides them leisure with time and space of their own; thus when in school they are no longer exploited. They will discover themselves and their potentials. They will acquire self-esteem and confidence. Moreover, educated girls have more economic opportunities and engage more fully in public life. Women who are educated tend to have fewer and healthier children who are more likely to attend school (Mahammad, 2007). For about a decade now Nigerian women/girl child education has been receiving attention from government and non-governmental organizations. Nigeria is involved in both ratification and implementation of various international conventions and resolutions and has in motion mechanism for bridging of the educational imbalance between boys and girls.

The Federal Ministry for Women Affairs and Youth Development, in order to 
enhance and ensure the education of the girl-child, has embarked on advocacy visits and enlightment campaigns through seminars, conferences, workshops, television and radio programmes on the importance of the girl-child education with a view to creating awareness and sensitizing the citizenry on issues affecting the girlchild (Manza. 2003)

Nigerian women in order to enhance their standard are agitating for their rights to participate in politics. Education provides women the opportunities to be able to read and write as well as do some arithmetical calculations. With education given to them the sky is their limit, that is, they can rise to any position or standard. If girls are educated they will cope with the complexities and challenges of the modern world.

From the above, it could be said that the provision of basic education to women becomes a fundamental right of every child. It is a fact that an educated house wife, mother or career woman can be a better house wife, mother and citizen. Looking at women (and girls) as mere child bearing machines and cooks is oldfashion and should be discarded (Salawu, 2006).

\section{Relevance of Girl-Child Education in Economic Recession}

Education and economic development are linked together with education being the determinant factor (Hamhian, 1999). That a minimum level of education will guarantee a reasonable high level of development. However. National Policy on Education establishes link between nation objectives stating: "The acquisition of appropriate skills, abilities and competences both mental and physical for individual to live and contribute to the development of his society (Salawu, 2006). There is a popular saying that girls are future mothers educate them for better society: if a girl child is educated a whole nation is educated, but if a boy is educated only an individual is educated. These assertions revealed that no meaningful achievement in all aspect of life could be recorded without all citizens been educated.

Thus, judging from the fore mentioned statements education of girl plays vital roles in the development of societies and economy which are the bedrock of national development.

\section{Man Power and Skill Capacity Development}

Girl child opportune to have access to education could contribute significantly in providing skills and expertise to individuals in various fields of endeavor. This is being done through programmes of training and remaining in knowledge, skills and attitude within and outside the school setting. Thus, girl child could assist in providing required man-power for gainful employment as well as opportunities for individual to continue to grow and advance in their chosen career. By so doing, individual becomes skilled, hence more productive to development of our resources. The societies advance more positively with educated person within it, likewise the economy boosted when workers acquired competences. 


\section{Career Opportunities}

According to Elele (2006), career refers to work or occupation that individual engages in his/her life time that aimed at producing societal acceptable benefit while making contribution to the society. This is closely related to man power development. Girl-child that has access to education has potentials to acquired wide range of occupations in both public and private organizations, from the fact that educated persons had better chances to be employed in our modern bureaucratic set up.

\section{Inculcating Appropriate Work Habits and Social Values}

It is a fact that women play vita role in the upbringing of their children who are leaders of tomorrow and builders of the community. Elevation of society, community or a nation could not be possible if mothers are not well educated. At a mothers lap is a child first school; she, to a great extent moulds her child's personality towards the right or wrong channels.

It is obvious that adequately educated mothers guide their children much more than the uneducated ones. During the growing stages, children become more inquisitive and ask more questions which only enlightened mothers can respond to give the positive direction which could aid to adapt the child best in the society, making him/her a useful member of the society, who can aspire for personal achievements and nation's development. Conversely, uneducated mothers cannot satisfy their children's thirst for knowledge. They are also not conversant with the dynamic global trends. Thus offer little or no guidance to their offspring's (Jibril-Daura, 2000).

\section{Problems of Girl-Child Education in a Period of Economic Recession}

Although various concerted efforts were made by the federal government of Nigeria to follow the right direction toward enhancing the accessibility of education of the Girl -child, yet the effort is still facing problems which includes.

\section{Poor Access to Equal and Quality Education}

Access to equal and quality education is one of major problems facing Girl child education in Nigeria. This is very common in urban centers where females are contributing to the economic up keeping of the households. Though, it is gradually failing away in some states particularly among the elite groups that have the means of sending their daughters to schools, while, to the middle-class the story is not the same if the family relies solely on money generated from hawking of water, selling beverages as well as participating in different types of child labour.

\section{Illiteracy}

The rate of females who are illiterates is higher than that of the males in Nigeria. There are also significant variations between the north and south. The enrolment of the girl-child in the south east is much higher than that of boys. The classical example could be found in Anambra and Enugu states their boys prefer learning trade to education. In 2000. the population of girl's enrolment in primary schools averaged $42.9 \%$. This 
shows a reduced access for girls in general. There are about six states in southern Nigeria where enrolment rates exceed $50 \%$, while thirteen states fall below the national average. Sokoto, Taraba and Zamfara have rates less than $30 \%$. At the higher levels of schooling. there is a continuing gap between boys and girls (IPG,2003).

\section{Socio-Cultural Factor}

According to Danyaya and Jabbi (2006) socio cultural factor significantly proves to be a retarding factor to girl-child education especially among Muslim communities. Traditionally, women are considered as perishable commodities and they are expected to retain and maintain their virginity to their matrimonial homes. In areas where this belief prevails, they viewed girl-child education as insignificant, since they may get abused in the school. On the other hand "married women are to abide by the obligation of getting permission from their husbands to attend their classes which on many occasion is not granted.

\section{Recommendations}

Government and various intervention agencies must as a matter of necessity work together to bring positive changes in the lives of the girl-child through functional education.

Women problems should be seen as national problems, as long as they are seen as women's problem only, the development mission will remain unsuccessful.
Effort must be made to improve opportunities available for education especially in the rural communities, through the provision of good roads. water, electricity and health facilities to allow them compete favorable with their urban counter parts.

- Education for girl-child should not only be made free but also compulsory at all level to prevent drop-out as a result of lack of funding. Recruitment exercise especially in secondary schools, colleges of education and university should be sanitized as the recruitment of immoral teachers and lecturers is becoming detrimental to girl-child education. Alternatively, law should be enacted against sexual abuse in the school system.

\section{Conclusion}

The importance of educating the girlchild cannot be over emphasized because through education people achieve development in diverse sectors of economy such as health care delivery, agriculture, transportation, information and communication technology, of all importance the education sector. The process and institutions involved in education have to be of high quality so as to achieve economic development. 


\section{References}

Badejo, O. O. (1991). The roles of Federal Government of Nigeria in women education; An appraisal Maiduguri Journal of" Education Studies (1) July. education, University of Maiduguri.

Elele. U. C. (2006). The place of Chemistry Nigeria youth career development. Journal of Women in Colleges of Education, 10:209-212.

Federal Republic of Nigeria (2004); National Policy on Education. Lagos Federal Government press.

Gurian, M. (2001) Boys and Girls Learn Differently; Sanfrancisco Jessie bass.

Hamman, B. K. (1999); The Role of Business Education in Development. Zaria Journal of studies in education, 7(1): 169178.

Independent Policy Group- Women Empowerment in Nation Building, IPG policy brief document, Abuja (2008).

Jibril-Daura, R. (20000) How to Increase Enrolment and Retention of Girls in Kaduna State Secondary Schools. Zaria Journal of studies in Education.

Kane, E. (1995). Seeing for yourself Research Hand Book for girls education in Africa Washington DC World Bank.
Luler, A. (1989). Nigeria and education; The Challenges Ahead, Ibadan Spectrum Books Ltd. P.12.

Mamza, C. A. (2003). Women Education and National Stability: A challenge for democracy: Bakatsina, 1(1): 106111.

Mang D. S. (2003). Women Education and National Stability: A challenge for democracy. Bakatsina 1 (1): 130-136.

Muhammad, N. (2007). Civil Child Labour and Education in Nigeria. In Muhammad N. and Mamman S. (Eds), Education for Special target Groups. Malumfashi, Albarka press. 